\begin{tabular}{l|l|l|l|l}
\hline Volume 1 & Issue 3 & December (2020) & DOI: 10.47540/ijsei.v1i3.60 & Page: $160-173$ \\
\hline
\end{tabular}

\title{
Effect of Heavy Metals Emissions on Ecosystem of Pakistan
}

\author{
Muhammad Asif ${ }^{1}$, Bushra Sharf ${ }^{2}$, Saqaina Anwar ${ }^{3}$ \\ ${ }^{1,3}$ Institute of Energy and Environmental Engineering, University of the Punjab, Punjab, Pakistan \\ ${ }^{2}$ Department of Chemistry, Lahore College for Women University, Lahore, Punjab, Pakistan \\ Corresponding Author: Muhammad Asif; Email: 03047092647asif@gmail.com
}

\begin{tabular}{|c|c|}
\hline A R T I C & E I N F O \\
\hline Keywor & Pollution; Heavy N \\
\hline Soil Pollu & on; Water Pollution. \\
\hline Received & : 01 July 2020 \\
\hline Revised & : 26 August 2020 \\
\hline Accepted & : 05 December 2020 \\
\hline
\end{tabular}

\section{A B S T R A C T}

Environmental contamination is one of the significant problems of modern society. Heavy metal pollutants include zinc, arsenic, nickel, cadmium, copper, lead, chromium, manganese, and iron etc. Their universal bioavailability accumulation in the food chain causes severe effects on human health. The lives of living species will be preserved by unique heavy metal treatments to improve the air, soil, and water quality. This review article represents a glimpse of heavy metal contamination in several areas of Pakistan over the past few years, that assess the heavy metal especially the contamination in water (groundwater, surface water, and wastewater), soil, and particulate matter. The listed pollution affects the quality of drinking water, the ecological environment, and the food chain. The toxicity induced by contaminated water, soil, and air causes a genuine threat to human health. Moreover, the technologies to overcome this problem have also been reported in it.

\section{INTRODUCTION}

Global environmental pollution is the fastestgrowing problem of the modern era. Heavy metals and their compounds play a significant role in threatened our ecosystem by their toxicity. The environment is known for its surroundings and conditions. All flora and fauna species along with abiotic habitat including aquatic, terrestrial, and atmosphere are greatly affected by the toxicity of heavy metal like pollutants which affect their typical activity by crossing their tolerance limit. It is an undesirable change in the surrounding that directly or indirectly affect the quality of water, air, and soil whom in turn affect the life of living organisms. It can take the form of chemical substances, energy, such as heat light, or noise (Wong, 2012).

An environment can be contaminated by various type of pollutants which are directly or indirectly exposed by human activity. And it became a challenge to the global society to get rid out of this. The contaminants in the form of heavy metals are appraised as naturally occurring compounds that in contact with the environment produce hazard effects and disturb the natural activity. They may be inorganic or organic. Environmental pollution has a direct relationship with the population. Rapid industrialization with increasing demands of the community leads to introduce potential toxic components in the environment. And it creates an alarming situation for our global society (Hill, 2020).

Inorganic pollutants introduced by heavy industries like chemicals, fertilizers, paints, dyes, oil and ghee, etc. Their vital components include metals, minerals, and salts. Literature reported that these pollutants are natural while there are exposed to the environment by human activities like mine drainage, chemical processes, metallurgical processes, etc. These pollutants show their toxicity in the surroundings by accretion in food chains $(\mathrm{Cd}$, $\mathrm{Cr}, \mathrm{Cu}, \mathrm{Hg}, \mathrm{Mn}, \mathrm{Ni}, \mathrm{Pb}, \mathrm{V}$, and $\mathrm{Zn}$ ). Metalloids like $\mathrm{As}, \mathrm{Bo}$, and $\mathrm{Sb}$, non-metal like Se, actinoids like Uranium, and halogens like Iodine and Fluorine also included in it. Mining activities are a source of toxicity. Some of these elements in trace quantity are essential for health while an excess of these elements causes severe diseases (Salomons, 1995).

These pollutants mainly produce by biodegradation. Anthropogenic activity, in this case, 
plays a role in contributing to environmental pollution. These are concerned with food waste, human waste, pesticides, aromatic hydrocarbons, and organochlorine pesticides. These pollutants show high solubility and stability. It is accumulated in the environment to cause a toxic effect (ElShahawi, Hamza, Bashammakh, \& Al-Saggaf, 2010; Van Ael, Covaci, Blust, \& Bervoets, 2012).

Heavy metals are naturally present under the earth's crust. Some of them exist in free states and some of them are present in the form of compounds. They exhibit various chemical properties and when they are exposed to the environment Heavy metals are naturally present under the earth's crust. Some of them exist in free states while most of them are present in form of compounds. They exhibit various chemical properties and when they are exposed to the environment during the mining process, they tend to create environmental pollution. Apart from mining processes, they also come into the

$$
\mathrm{M}+\text { organic matter } \quad \mathrm{H} 2 \mathrm{O}, \text { bacteria }
$$

These organic forms are reported as highly toxic and having an adverse effect on the quality of water by its leakage to pollute the underground sources of water (Pestemer \& Strumpf, 2003; environment via by-products during the formation of different products. They are emitted both in elemental and compound form. For example; Cadmium is emitted as a by-product in refining of zinc, lead is emitted during its mining and smelting activities, from vehicles by burning of fuels and then treated with TEL to form lead paints while mercury is emitted by degassing of the earth's crust.

Mining activities mostly result in the formation of acid mine drainage (AMD), a phenomenon commonly linked with mining activities. Literature survey shows that heavy metals (M) at mining sites are leached and carried by acidic water downstream. They can be acted upon by bacterial and methylated to yield organic forms, such as monomethyl mercury and dimethyl cadmium. This conversion is effected by bacteria in water, in the presence of organic matter, according to the following simplified equation.

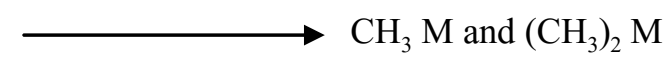

Sarkar, 2002). United States Environmental Protection Agency (USEPA) had taken a survey to report the maximum contamination levels for heavy metal concentrations in air, soil, and water.

Table 1. Concentration of heavy metal in contaminated air, soil, and water

\begin{tabular}{|l|l|l|l|l|}
\hline Heavy metal & $\begin{array}{c}\text { Max conc. in air } \\
\left(\mathrm{mg} / \mathrm{m}^{3}\right)\end{array}$ & $\begin{array}{c}\text { Max. conc. in } \\
\text { sludge (soil) }(\mathrm{mg} / \\
\text { Kg or ppm }\end{array}$ & $\begin{array}{c}\text { Max. conc. in } \\
\text { drinking water } \\
(\mathrm{mg} / \mathrm{l})\end{array}$ & $\begin{array}{c}\text { Max. conc. in } \\
\text { drinking water } \\
(\mathrm{mg} / \mathrm{l})\end{array}$ \\
\hline $\mathrm{Cd}$ & $0.1-0.2$ & 85 & 0.005 & $0.008^{\delta}$ \\
$\mathrm{Pb}$ & -- & 420 & $0.01^{\pi}$ & $0.0058^{\delta}$ \\
$\mathrm{Zn}$ & 1,5 & 7500 & 5.00 & $0.0766^{\delta}$ \\
$\mathrm{Hg}$ & -- & $<1$ & 0.002 & 0.1 \\
$\mathrm{Ca}$ & 50 & Tolerable & 50 & Tolerable $>50$ \\
$\mathrm{Ag}$ & 0.01 & -- & 0.0 & 0.1 \\
$\mathrm{As}$ & -- & -- & 0.01 & -- \\
\hline
\end{tabular}

The pollution created by heavy metal on the earth's surface as well as underground in sources of water creates soil pollution and this pollution also increases when mined ores are dumped on the ground surface for manual dressing. Surface dumping exposes the metals to air and rain thereby generating much AMD. When agricultural soils are polluted, these metals are taken up by plants and consequently accumulate in their tissues. Animals that feed on such contaminated plants and drink that polluted waters, as well as marine lives that breed in heavy metal polluted waters also accumulate such metals in their tissues, and milk, if lactating. Humans are in turn exposed to heavy metals by consuming contaminated plants and animals, and this has been known to result in various biochemical disorders. In short, all living organisms within a given ecosystem are variously contaminated along their cycles of the food chain (Tyler, 1972).

Similarly, the usage of industrial products in household demands also comes in contact. Mercury exposure is occurring through disinfectants, 
antifungal agents, toiletries, creams, and organometallics, cadmium exposure is through nickel/cadmium batteries and artist paints; lead exposure is through wine bottle wraps, mirror coatings, batteries, old paints, and tiles amongst others. Infants are more susceptible to the endangering effects of exposure to heavy metals (Duruibe, Ogwuegbu, \& Egwurugwu, 2007; Tyler, 1972).

Heavy metals are known as xenobiotics due to their non-beneficial role inside the living body even their minor concentrations are harmful. They are categorized as toxic metals. Pakistan is facing major environmental challenges for the last few decades due to fluctuations in its economic and social development. The toxicity of heavy metals on our ecosystem is eliminated from the point or non-point sources and severely affects the integrity of our ecosystem as well as has a great impact on human health. Heavy metals are known as inorganic pollutants which have to gain more attention from the public and scientific community in relation to their toxicity to aquatic organisms and ultimate effect on the well-being of humans. Heavy metals like iron, copper, chromium, and zinc are essential for metabolic activities, but become toxic at higher concentrations, whereas lead and cadmium have no documented role in living organisms. The migration of population from rural to urban areas for a better lifestyle made a haphazard situation in all its major big cities. Municipal authorities in this response not working properly. Similarly, all other service providers are also affected by this haphazard situation and failed to work properly. This situation greatly affects the natural resources of soil, air, and water (Malik \& Zeb, 2009).

Heavy metals produce both naturally and by anthropogenic activities. These metals are present in the environment i.e. air, soil, and water. Naturally, these metals are existing in form of hydroxide, sulphides, phosphates, oxides, silicates, and organic compounds. The most common heavy metals are Lead chromium, nickel, cadmium, zinc, mercury, arsenic, and copper. However, they have occurred in trace amounts but their little quantity is quite enough to cause severe health problems to the living (Herawati, Suzuki, Hayashi, Rivai, \& Koyama, 2000).

Some anthropogenic activities in industries, agriculture, mining, and waste-water also contribute to their release into the environment. These include automobile exhaust, smelting, burning of fossil fuels etc which release large amounts of lead, arsenic, copper, zinc, nickel, vanadium, tin, selenium, and mercury. Their amount in environment is increasing day by day by industries to meet the demands of growing population ( $\mathrm{He}$, Yang, \& Stoffella, 2005; Herawati et al., 2000).

\section{MATERIALS AND METHODS}

This article revealed the emission sources of heavy metals such as industries, power plants, and transport systems. Nowadays, environmental contamination is one of the significant problems of modern society. This article also highlighted the occurrence, chemistry, source of heavy metals (industries, transport, and power plants), heavy metal impact on living organisms, and also reconnaissance on the environmental status of Pakistan related to pollution, especially about heavy metals. A detailed discussion is also done on its effect on the ecosystem (effect on air, water, and soil). The pollution of air, soil, and water cannot be removed at once but gradually it can be reduced to improve the quality of the environment. So, by keeping above mention view this paper also explains pollution control techniques. The data written in this article is taken up from the file data source.

\section{RESULTS AND DISCUSSION Effects of heavy metals on ecosystem}

The release of heavy metals shows a severe impact on the quality of soil, air, and water.

\section{Effect on soil}

Agricultural soils show high levels of toxic elements due to the application of agrochemicals and sewage sludge. Vehicular emissions, industrial wastes, and wastewater sludge have a noticeable impact on the heavy metal on soils. Inorganic pollutants are mainly known as contaminants of soil. Soil is the ultimate sink for heavy metals released in the environment by anthropogenic activities.

Non-exhaust emissions due to wear and tear of vehicle parts such as brake, tire, and clutch are an important source of trace metals in the urban environment reported by Thorpe and Harrison in 2008 and Pant and Harrison in 2013. Industrial sources for the heavy metal $(\mathrm{Cu}, \mathrm{Pb}, \mathrm{Zn}$, and $\mathrm{Cr})$ 
contamination in the urban soil include electroplating, petrochemicals, dyes, pigments, ceramic, tanning, and textile industries. Contamination of urban soils by heavy metals is therefore a matter of major concern at local, regional, and global levels owing to its adverse effect on the urban ecosystem (Karim, Qureshi, \& Mumtaz, 2015).

The presence of heavy metal in soil destroys the whole ecosystem via contamination in the food chain. Intake of food through different sources brings life at risk. The quality of soil gets affected by direct ingestion, food chains, acidification of soil, porosity, and even natural chemistry is altered in this case (Karim et al., 2015; Musilova, Arvay, Vollmannova, Toth, \& Tomas, 2016).

\section{Effect on air}

The quality of air is greatly affected by the rapid increase in industrialization and urbanization. Due to the rapid increase in population growth, air pollution becomes a serious issue at the global environmental level. Air pollution has a direct relationship with climate change. It mainly occurs by the unnecessary exhaust gases from the chimneys of various industries. Greenhouse gases play a significant role in air pollution. The excess of these gases in the environment is causally linked to cause air pollution. On contact with other gases or molecules in the environment, they tend to create global warming which directly or indirectly affects the living species. These effects tend to reduce the biodiversity due to which species got extinct. A rise in temperature leads to lengthen the summertime period and shorten the winter season. Some particulate matter and dust are also reported as air pollutants. They took part naturally via soil erosions, rock weathering, dust storms, volcanic eruptions, and anthropogenic activities in industries and transportation (Soleimani, Amini, Sadeghian, Wang, \& Fang, 2018).

\section{Effect on water}

Water is the main element for life. Freshwater comprises almost $3 \%$ of the total water on earth. While a small percentage of $0.01 \%$ of this freshwater is available for human activities. But unfortunately, even this small proportion of freshwater is facing immense stress due to the rapid increase in population, urbanization, and unsustainable consumption of water in industry and agriculture. Heavy metal transportation from industrial sources greatly affects the quality of water. Improper sewage of industrial waste lead to cause severe disturbance in an ecosystem. Their traces are even very toxic that they cause severe health problems to the living species. The toxicity of these metals mainly depends on their interaction with organisms and their biological role inside the living body. Food chains and the Food web represent the relationships between organisms. Thus, contamination in water indirectly or directly affects all living organisms (Lee, Bigham, \& Faure, 2002).

\section{Heavy metal impacts on living organism}

The presence of heavy metal in the environment shows adverse impacts. These impacts cover all the surface of the earth due to which all food chain get disturb. An increase in temperature, unscheduled rainfall, increase humidity all depends on the emission of unnecessary emission of toxic compound in the environment. They tend to cause diarrhea, malaria, asthma, and some infection related to malnutrition in the children of the poor. They also increase the failure rate of the nervous system, cardiac, respiratory, and reproductive systems along with hematological and immunological problems (Singh, Gautam, Mishra, \& Gupta, 2011).

People exposed to high amounts of heavy metals may experience serious ailments, for example, gastrointestinal and renal toxicity, heart issues, different types of tumors, hematic, melancholy, tubular and glomerular dysfunctions, and osteoporosis. Newborn children, kids, and young people are especially immune to heavy metal, bringing about formative difficulties and low insight remainders. Most of the countries have framed the norms for the heavy metals allowable limit in the food to avoid its consumption (Duruibe et al., 2007; Rai, Gaur, \& Kumar, 1981).

\section{Status of environment in Pakistan}

In Pakistan, pollution is spread on a large scale at an uncontrollable rate. The major source of heavy metals elimination is industrial waste. Our air, soil, and water all are severely affected by the release of heavy metals in the form of gases, liquid, and solid contents. Soil plays an important role in the economy of agricultural land. And Pakistan earned $75 \%$ of the economy by its agricultural export. Agricultural soils show high levels of toxic elements due to the application of agrochemicals 
and sewage sludge. There are so many pollutants that take part in pollution. Vehicular emissions, industrial wastes, and wastewater sludge have a noticeable impact on the heavy metal on soils. The process of soil pollution is natural or by human activities. Natural pollution includes forest fires, acid rains, volcanoes, etc. while in human activities it includes mining, waste disposals from industries, fossil fuel combustions, smelting and sewage etc. Accidental pollution mainly occurred through natural disasters like a flood in rivers, nuclear attempts, landfills leakage etc. Excessive use of fertilizers and pesticides also leads to cause soil pollution. Mining activities are known as an important source of toxic elements, due to the legacy of contaminated sites. Soil degradation shows great impacts on the quality of water, air, and change in climate Reduction in the soil's capacity to support human communities and ecosystems, and to desertification. Moreover, it can also impair human health and threaten food and feed safety. Soil pollution affects the ecological functions of soils (Cachada, Rocha-Santos, \& Duarte, 2018; Chabbi, Baati, Dammak, Bahloul, \& Azri, 2020).

In Pakistan, a large area is occupied by industries like chemicals, textile, garments, paint and dyes, fertilizers, glass and cement, steel, oil and ghee, automobiles and batteries etc. These industries contribute to polluting the environment by the emission of hazardous gases and polluted the air quality. The Management of waste and global warming is the rising challenge of the 21 st century. The rapid increase in industrialization leads to an increase in the challenges to face. Heavy industries play a significant role in disturbing the natural climate. The global emission reported greenhouse gases (GHGs) like carbon dioxide, methane, nitrous, ferrous, aluminium oxides with a large concentration of chlorofluorocarbons as air pollutants. The concentration of carbon dioxide gas is very much greater as compared to the rest of the gases. Almost $65 \%$ of $\mathrm{CO} 2$ is eliminated globally by fossil fuel burnings while $11 \%$ of the rest of the gases are produced in the process of chemicals and forestry. Due to the high density of $\mathrm{CO} 2$, it remains on the biosphere of our earth and made human health at risk. Due to the increasing demand for industrialization to fulfill the requirement of humans, $\mathrm{CO} 2$ concentration is gradually increased and it is not good for the survival of life. In the case of methane, $10 \%$ of it is produced by paddy cultivation. In paddy fields, methane is produced by the degradation of organic matter via hydrolysis, methanogenesis, acidogenesis, and acetogenesis. While $\mathrm{N} 2 \mathrm{O}$ also occupied a major portion of greenhouse gases. It is emitted by agricultural soil by microbial activity like nitrification and denitrification. Nitrification and denitrification are reported as primary biological processes to utilize the inorganic compounds of nitrogen to produce $70 \%$ of the global $\mathrm{N} 2 \mathrm{O}$ emission. Overall, the cumulative $\mathrm{N} 2 \mathrm{O}$ emission is incredibly low as compared to the emission of $\mathrm{CH} 4$ but the global warming potential of $\mathrm{N} 2 \mathrm{O}$ is higher than methane and makes it more considerable while considering the extenuation of GHGs (Cachada et al., 2018).

Heavy industries like steel, energy, chemicals, and fertilizers play a significant role in bringing fluctuation in the national economy. The steel industry is a very well-known heavy industry to produce a large amount of $\mathrm{CO} 2$ by burning of coal. Steel slag and phosphor-gypsum are also produced as by-products in pyrometallurgical processes. In stainless steel industries, three tons of waste are produced mainly comprise of slag and dust. Slag contains metal oxides while dust contains a lot of gangues like $40 \%$ of iron oxide in it, other contents of waste include a lot of hazardous elements, such as $\mathrm{Cr}, \mathrm{Pb}, \mathrm{Ni}, \mathrm{Cd}, \mathrm{Zn}, \mathrm{Hg}, \mathrm{As}, \mathrm{Ag}, \mathrm{Cr}, \mathrm{Cu}, \mathrm{Fe}$, and other elements of platinum group and so on. Similarly, in the cement industry, $7 \%$ of $\mathrm{CO} 2$ is produced. These by-products are produced in millions of tons every year and still, the formation of waste load per unit area is increased with the ever-increasing industrial growth (Nidheesh \& Kumar, 2019).

In the soil of various regions of Pakistan, it is observed that there is a large variation in Cadmium level among the chosen sites, which ranged between 0.02 and $184 \mathrm{mg} / \mathrm{kg}$ from normal soil to contaminated soil with mining or other activities. In a study of Sargodha district, the highest concentrations of $\mathrm{Cd}$ in the soil was found to be $6.74 \mathrm{mg} / \mathrm{Kg}$ and the higher values of $\mathrm{Cd}$ in soil suggested the possible risk of $\mathrm{Cd}$ entering into the higher food chain which was reflected by the $\mathrm{Cd}$ accumulation by forage in the range of 1.14 to 4.20 $\mathrm{mg} / \mathrm{kg}$. In the soil of Islamabad Territory, the capital city of Pakistan, and the dusty road along Islamabad Expressway, Cd concentrations of 5.8-6.1 and 4.5- 
$6.8 \mathrm{mg} / \mathrm{kg}$, respectively, have been found (Kazi et al., 2006).

Lead, the concentration of $\mathrm{Pb}$ is found well below the tolerance range $(50-300 \mathrm{mg} / \mathrm{Kg})$ in normal soil due to applied sewage sludge. The only exclusion in the above statement is where the highest $\mathrm{Pb}$ concentration of $103000 \mathrm{mg} / \mathrm{kg}$ (mean $1753 \mathrm{mg} / \mathrm{kg}$ ) was detected in contaminated soil under-mining activities with a mean reference soil value of $70 \mathrm{mg} / \mathrm{kg}$ from Kohistan region, Gilgit Baltistan province. Moreover, the contamination of heavy metals especially $\mathrm{Pb}$ in roadside soil is related to the traffic density on the roads. In Pakistan, $\mathrm{Pb}$ concentration along National Highway-5 ranges from 12 to $176 \mathrm{mg} / \mathrm{kg}$ with a mean of $36.45 \mathrm{mg} / \mathrm{Kg}$ and the highest concentration of $176 \mathrm{mg} / \mathrm{kg}$ was found near the bypass road of Hyderabad city, Sindh Province, which is the fifthlargest industrial city of the country. The variations in the concentration of $\mathrm{Pb}$ in some areas are mainly due to heavy traffic, brick kilns, and usage of leaded gasoline (Manzoor et al., 2004).

Nickel is widely distributed in nature and is greatly found in animals, plants, and soil. The concentration of $\mathrm{Ni}$ in the soil is approximately in the range of $4-80 \mathrm{ppm}$. A large amount of $\mathrm{Ni}$ is released in the atmosphere due to natural as well as anthropogenic activities including fossil fuel consumption, industrial production (mining, smelting, and refining), use, and disposal of nickel compounds and alloys, and waste incineration. In soil samples, the highest concentration of $\mathrm{Ni}$ is 172 $\mathrm{mg} / \mathrm{kg}$ recorded from the contaminated Lahore site, while the mean reference value of $70 \mathrm{mg} / \mathrm{kg}$. Moreover, in another study conducted on the soil of the Jhangar Valley, Punjab province, the maximum total content of $\mathrm{Ni}$ was recorded as 81 $\mathrm{mg} / \mathrm{Kg}$ (Manzoor et al., 2004).

Copper is an essential element. According to European Standards, the tolerable concentration of $\mathrm{Cu}$ in soil (is $50-140 \mathrm{mg} / \mathrm{kg}$ having $(6<\mathrm{pH}<7$ ). In various regions of Pakistan, the $\mathrm{Cu}$ concentration in soil and dust ranges from $<6$ to $412 \mathrm{mg} / \mathrm{kg}$. The capital city of Pakistan (Islamabad) industrial area shows that the total concentration of $\mathrm{Cu}$ is in the range of 8.88-357.40 mg/kg (Manzoor et al., 2004).

Chromium an important element especially in the metallurgical/steel or pigment industry. Both of its oxidation forms $(+3$ and +6$)$ in the chemical are used primarily in pigments, metal finishing, and wood preservatives. The main source of $\mathrm{Cr}$ pollution is from dyestuffs and leather tanning when wastes are discharged directly into waste streams. In soil samples, the $\mathrm{Cr}$ content is present in the acceptable range of $100-150 \mathrm{mg} / \mathrm{kg}$ (Kazi et al., 2006).

Iron is an important element in the human body's metabolism. It acts as a catalyst and present in greater amounts than any other trace element. It functions as a part of several proteins, including enzymes and hemoglobin. The literature study on the soil of Pakistan reported (the anthropogenic pressure on soil in terms of heavy metal pollution through wastewater/sludge treatment or industrial activities. In the case of $\mathrm{Fe}$, this pressure builds up does not affect the plant growth as easily soluble and exchangeable fractions of $\mathrm{Fe}$ are very low in comparison with the total $\mathrm{Fe}$ content in soil. The range of $\mathrm{Fe}$ content in soil from different regions is 1 to $196 \mathrm{mg} / \mathrm{kg}$ (Kazi et al., 2006).

Zinc is known as an essential micronutrient and acts as a catalyst to do enzyme activity, contributes to protein structure, and regulates gene expression. Its deficiency has been recognized for many years, but it can be toxic when exposures exceed physiological needs. The average zinc content of the worldwide soils is estimated to be 70 $\mathrm{mg} / \mathrm{kg}$ which is the same average level of $\mathrm{Zn}$ in the earth's crust. The standard limit of $\mathrm{Zn}$ in soil by sewage sludge applications set by EU is $150-300$ $\mathrm{mg} / \mathrm{kg}$. In Pakistan soil, the concentration of $\mathrm{Zn}$ in soil/dust varies from $>0.1$ to $1193 \mathrm{mg} / \mathrm{kg}$ with only exception where the highest concentration of $\mathrm{Zn}$ in soil/dust was observed in contaminated area, that is, 29755. However, in roadside soil along the National Highway of Hyderabad, Sindh province, the $\mathrm{Zn}$ concentration varies from 13.8 to $180 \mathrm{mg} / \mathrm{kg}$ due to intense traffic (Kazi et al., 2006; Waseem et al., 2014).

In the case of water pollution, the increasing water demand is not be fulfilled due to the increasing quantity of effluent. Non-functional and poorly working factories and industries drain their effluents in improper ways. Out of 6634 registered industrial factories, 1228 are declared as a source of water pollution. In Karachi, $60 \%$ area is occupied by industries, and their effluents are directly drained in Malir Rivers. Around 300 million gallon discharge is recorded per day. Similarly, Hattar industrial area is well known for chemicals and 
ghee industries comprising on 700 acres but the lack of an improper drain system leads to water and soil pollution (Saifullah, Khan, \& Ismail, 2002).

Availability of safe and clean water to drink is very less in the cities. According to PCRWR survey, $23.5 \%$ of rural and $30 \%$ of urban areas have access to clean water. Pakistan's one-third area is comprising of groundwater reservoirs and it is a single source for municipalities for water supplies. The major pollutants of water pollution are the elimination of by-products from many industries like textile, metal, dying chemicals, fertilizers, pesticides, cement, petrochemical, energy and power, leather, sugar processing, construction, steel, engineering, food processing, mining, and others. This discharge is carried to drains and rivers to enhance the border of pollution. It was also estimated in that report that water-borne diseases led to the annual loss of Rs. 25-58 billion in national economy and over 2.5 lacs children suffer from diarrhea per year and $20-40 \%$ of hospitals are occupied by patients suffering from water-borne diseases, and it caused about one-third of all deaths (Hasnie \& Qureshi, 2002; M. Tahir, H. Rasheed, \& S. Imran, 2010).

According to a press release of UNO in 2002, almost 1.1 billion of Pakistan have lack of access to pure water for drinking purposes and almost more than 5 billion people died every year due to waterborne diseases. It was also reported that the world's population is increasing exponentially while the availability of fresh water is declining. According to that, till 2025 two thirds population of the world is likely to live in those countries which have moderate or severe water shortages". Many countries in Africa, the Middle East, and South Asia will have to face serious threats of water shortage in the next two decades. While, in the developing countries this problem is further aggravated due to the absence of proper management, unavailability of professionals, and financial constraint (Azizullah, Khattak, Richter, \& Häder, 2011).

Pakistan is in a critical situation of water shortage. It has fewer reservoirs for the storage of water and in near future, it has to face water scarcity because it has a low rate of precipitation as compared to the evaporation rate in the country so it continuously reducing the level of water in rivers, lakes, and seas. The per capita availability of water in Pakistan drops from 5000 in 1951 to $1100 \mathrm{~m} 3$ annually. The rapid increase in population and no expansion of water supplies may cause per capita water resources of less than $1000 \mathrm{~m}^{3}$ from the year 2010 onwards. The situation could deteriorate further in areas situated outside the Indus basin where the average per capita water supply is already below $1000 \mathrm{~m}^{3}$ annually. In the region of Sindh, drought-affected many populations that do not have fresh water for drinking and are forced to drink saline water. In Khairpur, out of 768 drinking water samples, $567(73.83 \%)$ and $351(45.70 \%)$ were contaminated with total bacteria and their discharge, respectively. In Baluchistan Province, the underground water sources are falling at a rate of $3.5 \mathrm{~m}$ per annum and will also be depleted in the next 15 years. The situation is the same in other major cities of the country like Peshawar, Lahore, and Karachi. In all these cities drinking water is found highly contaminated with bacteria and pathogens. Another study reported E.coli bacteria as a major source of contamination of water. A recent study of Rawal dam that is serving drinking water to almost 1.5 million population of Rawalpindi contains many bacteria (Iqbal, 2010).

The natural source of water contains contaminants of trace elements, heavy metals as it dissolves these substances while moving downward as a hydrological cycle. The introduction of these heavy metals in surface and underground water occurs via several human activities like large-scale use of chemicals in agriculture and improper removal of industrial and municipal wastes. Many of these metals are considered essential for human health but an excess of these metals has severe effects on human health. In Pakistan toxic metals in both ground and surface waters, often exceed the maximum permitted concentrations recommended by WHO for drinking water. Pakistan is an industrial land so disposed of waste is not proper and thus it results in water pollution. The results of various studies conducted on the contamination of water with toxic metals in Pakistan are summarized in Table

Heavy/toxic metals concentrations (mg/L) inground and surface water samples of Pakistan. Data are extracted from various individual studies and arranged chronologically based on the year of publication of the reviewed articles (Waseem et al., 2014). 
Zinc and copper are known as essential elements for humans, but excess elimination can lead to adverse health consequences. According to the world health organization, drinking water should contain $3 \mathrm{mg} / \mathrm{L}$ and $2 \mathrm{mg} / \mathrm{L}$ for $\mathrm{Zn}$ and $\mathrm{Cu}$, respectively. Just one study reports its excess concentration of about $4 \mathrm{mg} / \mathrm{L}$ found in Karachi a city of Sindh (Poulsen, 1998; M. A. Tahir, H. Rasheed, \& S. Imran, 2010).

Manganese is a naturally occurring mineral present in water, but human activities increase its concentration as compared to its tolerable rang. Intake of such water leads to a nervous breakdown (Mirhashemi \& Shahabaddin, 2011; M. A. Tahir et al., 2010).

Iron the most abundant element on earth, essential for the normal functioning of a living body. Its deficiency and excess can be harmful both for animals and plants. In Pakistan, it is considered as the major pollutant of water. A survey hosted by PCRWR in all cities of Pakistan reported 28\% of ground and $40 \%$ of surface water samples contain an excess of $\mathrm{Fe}$ as compare to the standard range mentioned by WHO (M. A. Tahir et al., 2010).

Cadmium is an element of great concern from its toxicity point of view. Its exposure causes chronic and acute health effects in living organism quantity when found in excess. The safe standard for $\mathrm{Cd}$ concentrations in drinking water set by $\mathrm{WHO}$ is $0.03 \mathrm{mg} / \mathrm{L}$ but the reported surveys elaborate that in KPK and Sindh its concentration is found much greater than Punjab. Intake of such water causes a gastrointestinal problem, chronic issues, kidney failure, damage of reproductive organs, and cancer due to its high-level toxicity (M. A. Tahir et al., 2010).

Chromium is the most common metal. It is highly toxic. According to PCRWR survey in Pakistan, only $1 \%$ of groundwater exceeds the safe limit. Analysis of drinking water samples from the residential area of Kasur showed chromium concentrations reaching $9.80 \mathrm{mg} / \mathrm{L}$. In general, chromium had 21-42 times higher concentrations than the recommended quality value that is $0.05 \mathrm{mg} / \mathrm{L}$. Frequently the high concentrations of chromium in the drinking water of cities like Lahore, Sialkot, and Gujrat have been traced from leather and tanneries industries. Its toxicity played an important role in the living body. Its hexavalent state $(\mathrm{Cr}+6)$ causes severe diseases like cancer, lung infection, irritants, respiratory, digestive, reproduction, and excretory system (M. A. Tahir et al., 2010).

Lead is a normal constituent of the earth's crust and its traces are also found in soil and water. The safe standard report by WHO for lead in drinking water is $0.01 \mathrm{mg} / \mathrm{L}$. However, in-country survey its concentration was found from 0.001 to $2.0 \mathrm{mg} / \mathrm{L}$ in groundwater and 0 to $0.38 \mathrm{mg} / \mathrm{L}$ in surface water. According to PCRWR survey $15 \%$ and $1 \%$ of surface and groundwater samples, respectively, had $\mathrm{Pb}$ above the safe limits. Its overdose causes fatal diseases inside the living body like the nervous, digestive, cardiovascular, reproductive, and immunological systems as well as the skeleton and the kidneys. Mercury is known as "persistent bioaccumulative toxin". It is naturally occurring in nature. Intake of this element is highly poisoned to the body. In Pakistan data regarding Hg containing contaminated water are limited as very few studies exist on the issue. PCRWR reported $\mathrm{Hg}$ concentrations beyond the safe limits in $5 \%$ of surface water samples but none in groundwater samples. Chashma showed $\mathrm{Hg}$ concentrations beyond the desire limits $(0.017 \mathrm{mg} / \mathrm{L})$. it is highly dangerous to marine life, deposited into the gills, and causes death (Martınez \& Motto, 2000; M. A. Tahir et al., 2010).

Arsenic is known as a big threat in Asian countries. In Pakistan, most reservoirs contain Astatine (As) metal in water beyond the safe limit reported by WHO. In the 1990s literature reported high concentrations of arsenic in the large water reservoirs of Pakistan, i.e. Tarbela, $(620 \mu \mathrm{g} / \mathrm{L})$, Chashma $(750 \mu \mathrm{g} / \mathrm{L})$. Similarly, in many areas of Sindh and Punjab, the drinking water was reported by PCRWR to have the maximum concentration of As that's not safe for human health (M. A. Tahir et al., 2010).

The overall situation of water contaminated by toxic metals shows the variation in their contamination level and frequency. All toxic metals except copper and zinc have their concentrations beyond the critical limits in many cases. Most of the authors linked the high concentration of heavy metals in the water to human activities like the disposal of industrial, municipal, and domestic wastes. Pakistan's major area is comprised of industrial areas, but they have no proper 
arrangement to discard the waste so the water from those industries moved and reached rivers, lakes, and sea and contaminate them. All agricultural land is also watered by this disposed wastewater due to which disease is becoming more common and causing death.

According to a survey of PCRWR for 20022006 following percentage was recorded in all provinces of Pakistan (M. A. Tahir et al., 2010).

Human activities are the cause of water pollution. The major part played by the industrial, domestic and municipal waste in water channels rivers, lakes, seas etc. Literature reported that around 2 million tons of waste and other effluents are disposed into the world's waters every day. In developing countries, this situation is worst where over $90 \%$ of raw sewage and $70 \%$ of untreated industrial wastes are dumped into the surface that reached to water source (Aziz, 2005).

Hattar industrial area is well known for chemicals and ghee industries comprising on 700 acres but lack of improper drain system. All their discharge effluents are dump into natural drains and ultimately collected in a drain near Wah. Due to a shortage of water, this contaminated water is used for agricultural land to grow fruits and vegetables (Sial Sr, 2006).

Air pollution is caused by the combustion of coal and excess use of fertilizers. Heavy metals in the atmosphere are usually present as a part of fine particles called particulate matter (PM10 or PM2.5). Respiration is one of the pathways for many metals to enter the human body. Heavy metals in the air are a matter of great concern; as we breathe, the polluted air directly transfers the contaminant air into the lungs. According to $\mathrm{WHO}$, the proposed value of $\mathrm{Cd}$ is $5 \mathrm{ng} / \mathrm{m}^{3}$ in air, however, it is highly dangerous to health. The IARC Working Group recently classified outdoor air pollution and particulate matter from outdoor air pollution as carcinogenic to humans (Simoneit, 2002).

Most of the studies from Pakistan report the airborne Cadmium concentration of less than 5 $\mathrm{ng} / \mathrm{m}^{3}$ (on an average basis) in the suspended particulate matter shown in Table 5. However, a report from Lahore shows the annual mean $\mathrm{Cd}$ concentration of $69 \mathrm{ng} / \mathrm{m}^{3}$ in PM2.5.

Lead has been acknowledged as one of the toxic constituents of airborne PM, with emission levels estimated at 450 million $\mathrm{kg}$ per annum from industrial coal and oil combustion and 30 million $\mathrm{kg}$ per annum from natural sources. The variations in the $\mathrm{Pb}$ concentration at some points may be due to traffic burden, brick kilns, and usage of leaded gasoline. Nowadays, the concentration of $\mathrm{Pb}$ in the urban 22 BioMed Research International atmosphere of Islamabad decreased in recent years due to the use of $\mathrm{Pb}$-free gasoline, although the $\mathrm{Pb}$ content is still at a high level, ranging from 0.002 to $4.7 \mathrm{ng} / \mathrm{m}^{3}$ (Riaz et al., 2017; von Schneidemesser, Stone, Quraishi, Shafer, \& Schauer, 2010).

Nickel in large amount released in the atmosphere due to natural as well as anthropogenic activities including fossil fuel consumption, industrial production (mining, smelting, and refining), use, and disposal of nickel compounds and alloys, and waste incineration. As per IARC, $\mathrm{Ni}$ compounds are human carcinogens by inhalation exposure; therefore, no safe level for nickel compounds can be recommended in the air. In the current analysis, the concentration of $\mathrm{Ni}$ in the particulate matter was reported in the range of $0.001-0.15 \mathrm{ng} / \mathrm{m}^{3}$, and the highest of its content was reported in the urban atmosphere of Islamabad (von Schneidemesser et al., 2010).

\section{Reduction of pollution}

The pollution of air, soil, and water cannot be removed at once but gradually it can be reduced to improve the quality of the environment. For example, in the case of air pollution, a forestation helps to minimize the concentration of $\mathrm{CO} 2$ due to the photosynthesis process. The absorption of $\mathrm{CO} 2$ by crops and agricultural orchard trees consider as the main sink of $\mathrm{CO} 2$ in the agriculture system. In the case of bio-energy with carbon capture and storage atmospheric $\mathrm{CO} 2$ is also removed by purpose-grown plants and trees, which are then harvested as biomass. The biomass can be burned to generate heat and electricity, with the majority of $\mathrm{CO} 2$ released during combustion being captured, liquefied, and sequestered in underground storage sites. The Direct Air Carbon Capture and Sequestration (DACCS) is another mature method to capture atmospheric $\mathrm{CO} 2$ and place it in ambient air into contact with a strong liquid base, such as potassium hydroxide or sodium hydroxide $(\mathrm{NaOH})$, which dissolves the $\mathrm{CO} 2$. This leads to a chemical reaction between the $\mathrm{CO} 2$ and base, forming a carbonate solution, from which the $\mathrm{CO} 2$ can then be removed in a separate process that involves 
combining the carbonate solution with calcium hydroxide $(\mathrm{Ca}(\mathrm{OH}) 2$ solution in a precipitator. This regenerates the base and forms solid calcium carbonate $(\mathrm{CaCO} 3)$, which is precipitated out of the base solution. The precipitate is then sent to a calciner, where it is reacted at extremely high temperatures (about $800^{\circ} \mathrm{C}$ ) with oxygen $(\mathrm{O} 2)$ from an air-separation unit, forming pure $\mathrm{CO} 2$ and calcium oxide $(\mathrm{CaO})$. The $\mathrm{CaO}$ is combined with water in a slacker and forms $\mathrm{Ca}(\mathrm{OH}) 2$ for reuse (Gambhir \& Tavoni, 2019; Johnston \& Keough, 2005; Nishitani, Kaneko, Fujii, \& Komatsu, 2011).

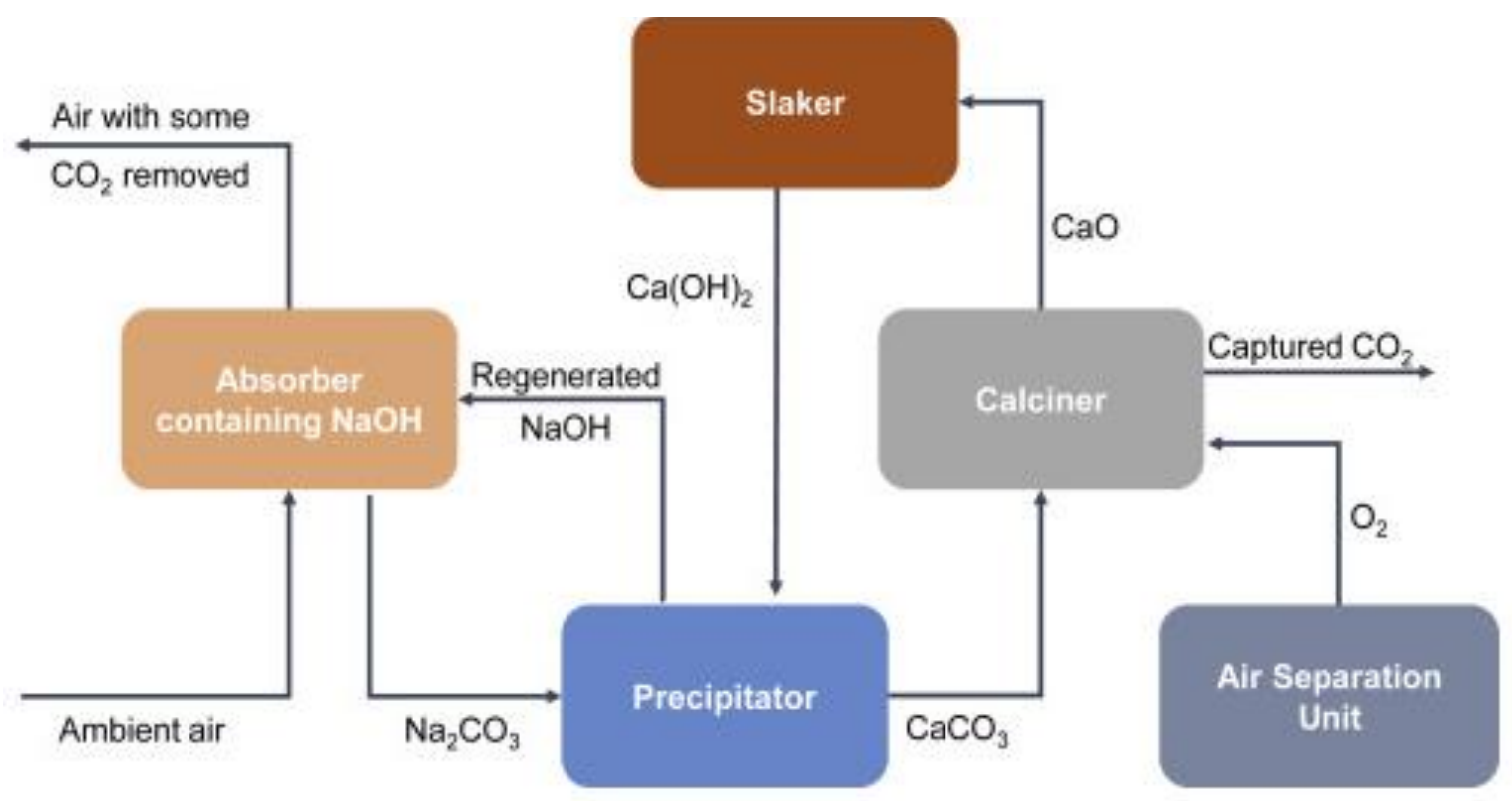

Figure 3: Direct air carbon capture and Sequestration (DACCS)

Ecologically, DACCAS has a low impact on the ecosystem as compared to BECCS. Some DACCS plant designs involve no water removal in their operations, although water removals during the manufacture of sorbents may be significant. There are also potential adverse consequences if the chemicals used for sorbent manufacture, and the disposal of sorbents at the end of their useful lives, are not handled in an environmentally responsible manner. In particular, the sodium hydroxide used in some DACCS plants is highly corrosive, and the chlorine gas by-product that results from its production from brine is highly poisonous (Fasihi, Efimova, \& Breyer, 2019; Gambhir \& Tavoni, 2019; Socolow et al., 2011).

A variety of technologies, product design choices, and operational approaches can rapidly and cost-effectively reduce energy consumption and GHG emissions across a broad range of industries. All these technologies and practices can be enhanced by integrated systems design. Over $90 \%$ of GHG emissions are from about a dozen industries, so exceptionally large reductions in industrial GHG emissions are possible by focusing on a limited set of product and process improvements (Gambhir \& Tavoni, 2019).

The use of municipal solid waste as an alternative material in cement production largely reduces net carbon dioxide and other greenhouse gas emissions. The use of decarbonated raw materials like steel slag, concrete waste, fly ash, etc. in place of limestone, reduces the carbon dioxide emissions both related to the calcination process and fuel combustion. the use of other fuels instead of conventional fuels reduces the carbon dioxide emission significantly. The use of "engineered fuel" in the cement industry will reduce 3 tonnes of $\mathrm{CO} 2$ per ton of alternative fuel used (Lei, Zhang, Nielsen, \& He, 2011).

\section{Co-processing}

Co-processing of waste is a promising solution for waste management and sustainable cement production. For example, the utilization of hazardous liquid waste as an alternative fuel in the cement industry reduces the environmental impacts associated with freshwater ecotoxicity, acidification, and global warming; while it enhances the environmental impacts associated with 
eutrophication and increases human toxicity impacts for cancer. Due to these types of issues, the anti-incineration movement is going on in some countries against this waste utilization in the cement industry (Buzzi, Viegas, Rodrigues, Bernardes, \& Tenório, 2013; Hasanbeigi, Lu, Williams, \& Price, 2012).

\section{Membrane technologies}

Membrane technology is a growing technology in leading to reduce pollution by its separation properties. The use of membranes for the recovery of acid mine drainage is very much effective in reducing water pollution. The pollutant in high concentration moves in the opposite direction with a concentration gradient phenomenon called reverse osmosis. Different kinds of membranes are used for such purposes i.e.: ultra-filtration, micro-filtration, nanofiltration, reverse osmosis, and particle filtration. Municipal authorities should have made proper methods for dumping industrial waste to reduce water pollution. The separation of metals and gases via membranes is recycled and reused in other various important treatments and products. And thus, marine life and water reservoirs are protected from pollution (Buzzi et al., 2013; Neoh, Noor, Mutamim, \& Lim, 2016; Nleya, Simate, \& Ndlovu, 2016).

\section{Biosorption}

The use of biological materials in the removal of contaminants from water is referred to as biosorption. It involves absorption, adsorption, surface complexation, ion exchange, and precipitation. These bio sorbents work with great efficiency and capacity with easy use. The regeneration process makes it more favorable. However, the high concentration of feed solution reduces further pollutant removal (Silvas, Buzzi, Espinosa, \& Tenório, 2011).

Most physical and chemical-heavy metal removal techniques require the handling of a large amount of sludge. Thus, to protect the ecosystem, the use of the above-mentioned technique should be carried out with proper and careful attention (Dermont, Bergeron, Mercier, \& Richer-Laflèche, 2008).

\section{ConCLUSION}

The environment is everything that creates natural conditions for the existence of living organisms. Heavy metals are toxins, releasing directly into the environment are a serious threat to human life and other living organisms due to their easy accumulation in the food chain. The activity of industries played a great role in this concern. So, proper strategies should be made to counterbalance the population and industrialization. Old technologies must be replaced by modern technologies such as membrane separation and biosorption for industrial waste processing. Moreover, the dumping of industrial waste should also be in proper ways to reduce environmental pollution. Due to the low efficiencies of old technologies, the emissions of pollutants affect our ecosystem very badly. We should have a better alternative to avoid the loss of human health and the entire ecosystem.

\section{REFERENCES}

Aziz, J. (2005). Management of source and drinking-water quality in Pakistan. EMHJEastern Mediterranean Health Journal, 11 (5-6), 1087-1098, 2005.

Azizullah, A., Khattak, M. N. K., Richter, P., \&Häder, D.-P. (2011). Water pollution in Pakistan and its impact on public health-a review. Environment international, 37 (2), 479-497.

Buzzi, D. C., Viegas, L. S., Rodrigues, M. A. S., Bernardes, A. M., \&Tenório, J. A. S. (2013). Water recovery from acid mine drainage by electrodialysis. Minerals Engineering, 40, 82-89.

Cachada, A., Rocha-Santos, T., \& Duarte, A. C. (2018). Soil and pollution: an introduction to the main issues Soil pollution (pp. 1-28): Elsevier.

Chabbi, I., Baati, H., Dammak, R., Bahloul, M., \&Azri, C. (2020). Toxic metal pollution and ecological risk assessment in superficial soils of "rural-agricultural and coastal-urban" of Monastir region, Eastern Tunisia. Human and Ecological Risk Assessment: An International Journal, 1-20.

Dermont, G., Bergeron, M., Mercier, G., \& RicherLaflèche, M. (2008). Soil washing for metal removal: a review of physical/chemical technologies and field applications. Journal of hazardous materials, 152 (1), 1-31.

Duruibe, J. O., Ogwuegbu, M., \&Egwurugwu, J. (2007). Heavy metal pollution and human 
biotoxic effects. International Journal of physical sciences, 2 (5), 112-118.

El-Shahawi, M., Hamza, A., Bashammakh, A., \& Al-Saggaf, W. (2010). An overview on the accumulation, distribution, transformations, toxicity and analytical methods for the monitoring of persistent organic pollutants. Talanta, 80 (5), 1587-1597.

Fasihi, M., Efimova, O., \&Breyer, C. (2019). Techno-economic assessment of $\mathrm{CO} 2$ direct air capture plants. Journal of cleaner production, 224, 957-980.

Gambhir, A., \&Tavoni, M. (2019). Direct Air Carbon Capture and Sequestration: How It Works and How It Could Contribute to Climate-Change Mitigation. One Earth, 1 (4), 405-409.

Hasanbeigi, A., Lu, H., Williams, C., \& Price, L. (2012). International Best Practices for PreProcessing and Co-Processing Municipal Solid Waste and Sewage Sludge in the Cement Industry: Ernest Orlando Lawrence Berkeley National Laboratory, Berkeley, CA (United ....

Hasnie, F., \& Qureshi, N. (2002). Quantification of pollution load in wastewater channels of village Rehri draining in to Korangi Creek. Pakistan Steel Research Journal, 3, 47-54.

He, Z. L., Yang, X. E., \&Stoffella, P. J. (2005). Trace elements in agroecosystems and impacts on the environment. Journal of Trace elements in Medicine and Biology, 19 (2-3), 125-140.

Herawati, N., Suzuki, S., Hayashi, K., Rivai, I., \& Koyama, H. (2000). Cadmium, copper, and zinc levels in rice and soil of Japan, Indonesia, and China by soil type. Bulletin of environmental contamination and toxicology, 64 (1), 33-39.

Hill, M. K. (2020). Understanding environmental pollution: Cambridge University Press.

Iqbal, A. R. (2010). Water Shortage in Pakistan-A Crisis around the Corner. ISSRA Papers, 2 (2), 1-13.

Johnston, E. L., \& Keough, M. J. (2005). Reduction of pollution impacts through the control of toxicant release rate must be siteand season-specific. Journal of Experimental Marine Biology and Ecology, 320 (1), 9-33. doi:

https://doi.org/10.1016/j.jembe.2004.12.024

Karim, Z., Qureshi, B. A., \& Mumtaz, M. (2015).

Geochemical baseline determination and pollution assessment of heavy metals in urban soils of Karachi, Pakistan. Ecological Indicators, 48, 358-364.

Kazi, T. G., Jamali, M. K., Siddiqui, A., Kazi, G., Arain, M., \& Afridi, H. (2006). An ultrasonic assisted extraction method to release heavy metals from untreated sewage sludge samples. Chemosphere, 63 (3), 411420.

Koehlmoos, T. P., Anwar, S., \&Cravioto, A. (2011). Global health: chronic diseases and other emergent issues in global health. Infectious Disease Clinics, 25 (3), 623-638.

Lee, G., Bigham, J. M., \& Faure, G. (2002). Removal of trace metals by coprecipitation with $\mathrm{Fe}, \mathrm{Al}$ and $\mathrm{Mn}$ from natural waters contaminated with acid mine drainage in the Ducktown Mining District, Tennessee. Applied Geochemistry, 17 (5), 569-581.

Lei, Y., Zhang, Q., Nielsen, C., \& He, K. (2011). An inventory of primary air pollutants and $\mathrm{CO} 2$ emissions from cement production in China, 1990-2020. Atmospheric

Environment, 45 (1), 147-154.

Malik, R. N., \& Zeb, N. (2009). Assessment of environmental contamination using feathers of Bubulcus ibis L., as a biomonitor of heavy metal pollution, Pakistan. Ecotoxicology, 18 (5), 522-536.

Manzoor, S., Shah, M., Shaheen, N., Tariq, S., Khaliq, A., \& Jaffar, M. (2004). Distribution of Heavy Toxic Metals in Industrial Effluents and Relevant Soils. Jour. Chem. Soc. Pak. Vol, 26 (4), 429.

Martınez, C., \& Motto, H. (2000). Solubility of lead, zinc and copper added to mineral soils. Environmental pollution, 107 (1), 153-158.

Mirhashemi, S. M., \&Shahabaddin, M.-E. (2011). Evaluation of aluminium, manganese, copper and selenium effects on human islets amyloid polypeptide hormone aggregation. Pakistan Journal of Biological Sciences, 14 (4), 288.

Musilova, J., Arvay, J., Vollmannova, A., Toth, T., \& Tomas, J. (2016). Environmental contamination by heavy metals in region with previous mining activity. Bulletin of 
environmental contamination and toxicology, 97 (4), 569-575.

Neoh, C. H., Noor, Z. Z., Mutamim, N. S. A., \& Lim, C. K. (2016). Green technology in wastewater treatment technologies: integration of membrane bioreactor with various wastewater treatment systems. Chemical engineering journal, 283, 582-594.

Nidheesh, P., \& Kumar, M. S. (2019). An overview of environmental sustainability in cement and steel production. Journal of cleaner production, 231, 856-871.

Nishitani, K., Kaneko, S., Fujii, H., \& Komatsu, S. (2011). Effects of the reduction of pollution emissions on the economic performance of firms: an empirical analysis focusing on demand and productivity. Journal of Cleaner Production, 19 (17-18), 1956-1964.

Nleya, Y., Simate, G. S., \& Ndlovu, S. (2016).

Sustainability assessment of the recovery and utilisation of acid from acid mine drainage. Journal of Cleaner Production, 113, 17-27.

Pestemer, W., \&Strumpf, T. (2003). Occurance, importance and legal regulations of heavy metals in urban stands-an overview. Paper presented at the Second International Symposium on plant health in urban horticulture, Berlin, Germany, 27-29 August, 2003.

Poulsen, H. D. (1998). Zinc and copper as feed additives, growth factors or unwanted environmental factors. J. Anim. Feed Sci, 7 (suppl 1), 135-142.

Rai, L., Gaur, J., \& Kumar, H. (1981). Phycology and heavy-metal pollution. Biological Reviews, 56 (2), 99-151.

Riaz, M. A., Tabinda Akhtar, A. B., Riaz, A., Mujtaba, G., Ali, M., \& Ijaz, B. (2017). Heavy metals identification and exposure at workplace environment its extent of accumulation in blood of iron and steel recycling foundry workers of Lahore, Pakistan. Pakistan Journal of Pharmaceutical Sciences, 30 (4).

Saifullah, S., Khan, S., \& Ismail, S. (2002). Distribution of nickel in a polluted mangrove habitat of the Indus Delta. Marine pollution bulletin, 44 (6), 570-576.
Salomons, W. (1995). Long-term strategies for handling contaminated sites and large-scale areas Biogeodynamics of pollutants in soils and sediments (pp. 1-30): Springer.

Sarkar, B. (2002). Heavy metals in the environment: CRC press.

Sial Sr, R. A. (2006). Quality of Effluents from Hattar Industrial Area Pakistan.

Silvas, F. P. C., Buzzi, D. C., Espinosa, D. C. R., \&Tenório, J. A. S. (2011). Biosorption of AMD metals using Rhodococcusopacus. Rem: Revista Escola de Minas, 64 (4), 487 492.

Simoneit, B. R. (2002). Biomass burning-a review of organic tracers for smoke from incomplete combustion. Applied Geochemistry, 17 (3), 129-162.

Singh, R., Gautam, N., Mishra, A., \& Gupta, R. (2011). Heavy metals and living systems: An overview. Indian journal of pharmacology, 43 (3), 246.

Socolow, R., Desmond, M., Aines, R., Blackstock, J., Bolland, O., Kaarsberg, T., . . Sawyer, K. (2011). Direct air capture of CO2 with chemicals: a technology assessment for the APS Panel on Public Affairs: American Physical Society.

Soleimani, M., Amini, N., Sadeghian, B., Wang, D., \& Fang, L. (2018). Heavy metals and their source identification in particulate matter (PM2. 5) in Isfahan City, Iran. Journal of environmental sciences, 72, 166-175.

Tahir, M., Rasheed, H., \& Imran, S. (2010). Water Quality Status in Rural Areas of Pakistan. Pakistan Council of Research in Water Resources, Islamabad, Pakistan: Report.

Tahir, M. A., Rasheed, H., \& Imran, S. (2010). Water quality status in rural areas of Pakistan: Pakistan Council of Research in Water Resources.

Tyler, G. (1972). Heavy metals pollute nature, may reduce productivity. Ambio, 1 (2), 52-59.

Van Ael, E., Covaci, A., Blust, R., \&Bervoets, L. (2012). Persistent organic pollutants in the Scheldt estuary: environmental distribution and bioaccumulation. Environment International, 48, 17-27.

von Schneidemesser, E., Stone, E. A., Quraishi, T. A., Shafer, M. M., \& Schauer, J. J. (2010). Toxic metals in the atmosphere in Lahore, 
Pakistan. Science of the Total Environment, 408 (7), 1640-1648.

Waseem, A., Arshad, J., Iqbal, F., Sajjad, A., Mehmood, Z., \& Murtaza, G. (2014).

Pollution status of Pakistan: a retrospective review on heavy metal contamination of water, soil, and vegetables. BioMed research international, 2014.

Wong, M. H. (2012). Environmental contamination: Health risks and ecological restoration: CRC Press. 